\title{
IMPACT OF CELEBRITY ENDORSEMENT ON CONSUMERS BUYING BEHAVIOR
}

\section{Imran Hussain}

\begin{abstract}
The rapidly evolving market conditions and intense competition between the firms, force marketers to adopt competitive strategies to promote their product to the right customer. Recent developments in consumer behavior and marketing studies emphasize various elements which impose an influencing impact on consumers and persuade them towards purchase intentions. This study explores the impact of celebrity endorsement and the mediating effect of consumer attitude on consumer purchase intention in a developing country. The study has employed a quantitative research design for which a selfadministrated structured research questionnaire was administered. the data were collected from 100 university students as respondents. The findings indicate that there is a strong influence on celebrity endorsements on university students. The celebrity endorser who possesses attributes such as likability, attractiveness, credibility, and personality has a positive influence on consumer's purchase intentions. Moreover, celebrity endorsements create a positive impact on consumers attitudes towards endorsed brands and products which stimulate the purchase intention. This research provides some useful theoretical and practical implications for researchers and marketers on the use of celebrity endorsers.
\end{abstract}

Keywords: Celebrity Endorsement; Likeability; Credibility; Personality; Attractiveness; Buying Behavior and Attitude.

\section{INTRODUCTION}

In today's world celebrities are considered role models especially to the youth. People are changing their living style related to their favorite celebrities (Ahmed, Seedani, Ahuja, \& Paryani, 2015). Celebrities are individuals who are well-known to the public due to their accomplishments in areas such as sports, entertainment, politics, broadcasting, corporate and others (Muda, Musa, Naina, \& Borhan, 2014). Celebrity endorsements create a great impact on the buying behavior of the persons. It attracts customers and ultimately increases company productivity. Celebrities are not always creating any kind of effect on a person's mind in terms of buying. However, mostly it gives a great impact on 
the perception of choosing any product. One always think that if their favorite celebrity is using a certain product then they should also use it to be like them (Ahmed et al., 2015).

For the last 150 years, advertising is changing in different phases from the classical to modern advertisement realms. Nowadays it is the best strategy used by marketers to influence customers by showing celebrities with their products, it includes different appeals, including fantasies, lies, excitement, absurdity, sexual arousal etc. The main aim of formulating such strategies is to get high brand revelation, longing, concentration, and curiosity and to do so, marketers attach famous personalities' with their products (Ahmed et al., 2015). Previous studies have shown that celebrityendorsed products can create a more positive response to consumers' buying behavior resulting in a positive attitude. However, some studies have found a weak relationship between celebrity endorsement, and consumer attitude towards brands, while some indicate a strong correlation between the two variables (Jamil \& Rameez ul Hassan, 2014). Similarly, some of the studies have revealed some disagreements on the exact role celebrity endorsement has on consumer behavior and brand (Abdurrahaman, Owusu, Soladoye, \& Kalimuthu, 2018).

In the light of these assertions and previous research findings this study intends to investigate the answers to the following research questions:

- Is there a positive or negative impact of celebrity-endorsed products on buying behaviors of consumers?

- Is there any impact of celebrity likability on consumers' attitude and buying behavior?

- How celebrity credibility influences consumers' buying behaviors?

- How personality of a celebrity effects attitude and buying behaviors of customers?

- How much importance does celebrity attractiveness have on customers' buying behaviors?

\section{RESEARCH OBJECTIVES}

Following are the research objectives of this study:

- To investigate the impact of celebrity-endorsed products on consumers' buying behavior.

- To study if there is a positive or negative attitude of a consumer regarding celebrity endorsed products.

- To study whether there is an importance of celebrity personality/appearance and attractiveness to influence the buying behavior and attitude of the consumers.

- To study the impact of likeability and credibility of celebrity on consumers' attitude. 


\section{SIGNIFICANCE OF THE STUDY:}

Selecting the right celebrity in advertising is critical. Celebrity endorsements generate brand awareness and play a vital role in ensuring the success of a campaign. It also helps to promote products and build credibility and help attract consumers. Celebrity endorsement direct influence the consumers buying behaviors and positive attitudes towards the product. Last but not least through celebrity endorsement consumers believe that they are getting a high quality product.

\section{RESEARCH SCOPE}

As per our research this study emphasis on the main factors that help to enhance consumers' buying behavior and consumers' attitude fora a product through celebrity endorsement. This research also focuses on marketer's perspective advantages through celebrity endorsements such as brand loyalty, profitability, consumer retention and good image of the company.

\section{LITERATURE REVIEW}

\section{Celebrity Endorsement}

The celebrity endorsement is a promotion strategy to attract customers (Osei-Frimpong, Donkor, \& Owusu-Frimpong, 2019). By analyzing the current market, it has become the need of the marketers to use the different famous personalities to relate with their brands to create a unique identity of the brand and to do famous his company's brand or product, which results in high expenditure for the company to use that strategy, however nowadays it is used to be a powerful strategic tool to get maximum profit (Ahmed et al., 2015).

\section{Buying Behavior}

Consumer buying behavior or Consumer purchase intention refers to the personal inclinations and actions related to the product. It may also be defined as an individual's conscious plan to make an effort to buy a brand or the person's motivation in the sense of his/her conscious plan to exert effort to carry out a behavior. Some studies revealed that famous people are mostly used as brand ambassador/endorser due to their high reputation among the people and they are also well recognized among a large group of the population as well. One of the other reasons for consumer buying intention is that most people follow other people with whom they associate themselves in terms of personality and other positive attributes, which they find in the famous personalities. Therefore, famous 
personalities often become the medium of spreading brand awareness through commercials since they gain more attention, recall and loyalty among a large group of audience (Priyankara, Weerasiri, Dissanayaka, \& Jinadasa, 2017).

Some other studies revealed that cognitive and affective dimensions are influenced differently by negative information (White, Goddard, \& Wilbur, 2009). Apart from this, negative information about celebrity might lead to a negative attitude towards the brand, new venture, or promotion. According to some researches, celebrity endorsement is taken as strategic promotion (Abdurrahaman \& Osman, 2017).

\section{Consumer Attitude}

Attitude refers to an individual internal evaluation pertaining to any object, issue, person, or action. Most of the researchers consider attitude as a key factor to come to know the consumer buying behavior related to any brand, product, or services. Studies suggested that celebrity endorsers would positively influence the attitude of a larger population. However, a negative attitude towards any celebrity might affect consumer buying behavior towards any particular brand or services. Previous Literature claimed that a positive attitude will boost the purchase intention of consumers (Abdurrahaman \& Osman, 2017).

\section{Celebrity Likability}

Celebrity likeability is the "affection for the celebrity as a result of the celebrity's physical appearance and behavior" (Priyankara et al., 2017)

\section{Celebrity Credibility}

Celebrity credibility is "the extent to which the recipient sees the celebrity as having relevant knowledge, skills, or experience and trusts the source to give unbiased, objective information"(Priyankara et al., 2017)

\section{Celebrity Personality}

The celebrity-persona para-social identification scale (CPI) is designed to measure how media consumers develop identification with celebrities or popular fictional characters. Identification is defined as a persuasion process that occurs when an individual adopts the behavior or attitudes of another individual or group based on a self-defining relationship (Choi \& Rifon, 2009). Identification is a psychological orientation through which individuals define themselves based on their group membership and derive "strength and a sense of identity" from the affiliation (Priyankara et al., 2017). 


\section{Celebrity Attractiveness}

The concept of attractiveness does not only entail physical attractiveness. Attractiveness also entails concepts such as intellectual skills, personality properties, way of living, athletic performances, and skills of endorsers (Adam \& Hussain, 2017). Celebrities can be attractive because they established for example great sports performances and people have great respect for their achievement and therefore they are attracted to them (Priyankara et al., 2017)

\section{CONCEPTUAL FRAMEWORK}

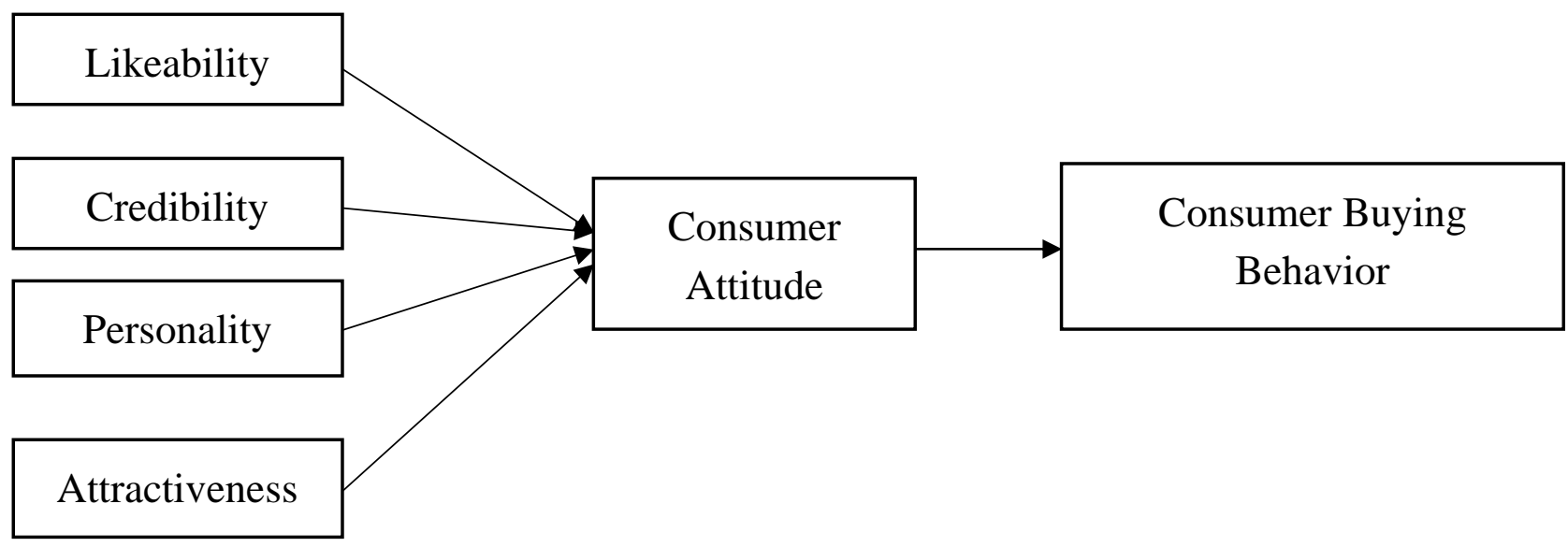

Operationalization of Variables

\begin{tabular}{llll}
\hline \multicolumn{1}{c}{ Variables } & & \multicolumn{2}{c}{ Items } \\
\hline Likability & Affection & Believable & Pleasing \\
\hline Credibility & Honest & Sincerity & Confidence \\
\hline Personality & Good look & Skill & Courage \\
\hline Attractiveness & Desire & Attention & Appearance \\
\hline Consumer Attitude & Positive attitude & Motivation & Negative attitude \\
\hline Consumer Behavior & Creditability & Personality & Likeability \\
\hline
\end{tabular}

\section{RESEARCH HYPOTHESES}

Ha-1: The consumer attitude mediates a direct relationship between likeability and consumer buying behaviour.

Ha-2: The consumer attitude mediates a direct relationship between credibility and consumer buying behavior. 
Ha-3: The consumer attitude mediates a direct relationship between personality and consumer buying behaviour.

Ha-4: The consumer attitude mediates a direct relationship between attractiveness and consumer buying behavior.

H0-1: The consumer attitude mediates no relationship between likeability and consumer buying behaviour.

H0-2: The consumer attitude mediates no relationship between credibility and consumer buying behavior.

H0-3: The consumer attitude mediates no relationship betweenw personality and consumer buying behaviour.

HO-4: The consumer attitude mediates no relationship between attractiveness and consumer buying behavior.

\section{RESEARCH METHODOLOGY}

\section{Research Design}

This research is a quantitative study as a theory is intended to be tested not developed, thus the study is cross-sectional research and explanatory in nature. To conduct the research and for data collection, the authors have used a survey questionnaire i.e., the primary source of data to collect information and data from the selected sample. Whereas the type of investigation in this research is causal (cause and effect) as the impact of celebrity endorsement on consumers' buying behavior and attitude is investigated. The sample size of this study is 100 university students from the Institute of Business Management Karachi, whereas the sampling frame was formulated with the help of the cluster sampling technique.

\section{DATA ANALYSIS AND RESULTS}

\section{Respondents Demographics}

\section{Table 1: Gender}

\begin{tabular}{|c|c|c|c|c|c|}
\hline \multicolumn{6}{|c|}{ Gender } \\
\hline & & Frequency & Percent & Valid Percent & Cumulative Percent \\
\hline \multirow[t]{3}{*}{ Valid } & Male & 116 & 58.0 & 58.0 & 58.0 \\
\hline & Female & 84 & 42.0 & 42.0 & 100.0 \\
\hline & Total & 200 & 100.0 & 100.0 & \\
\hline
\end{tabular}


Table 2: Age

\begin{tabular}{|c|c|c|c|c|c|}
\hline \multicolumn{2}{|c|}{} & Frequency & Percent & Valid Percent & Cumulative Percent \\
\hline \multirow{3}{*}{ Valid } & $18-24$ & 121 & 60.5 & 60.5 & 60.5 \\
\cline { 2 - 6 } & $25-30$ & 68 & 34.0 & 34.0 & 94.5 \\
\cline { 2 - 6 } & 30 above & 11 & 5.5 & 5.5 & 100.0 \\
\cline { 2 - 6 } & Total & 200 & 100.0 & 100.0 & \\
\hline
\end{tabular}

Table 3: Social Status

\begin{tabular}{|l|l|c|c|c|c|}
\hline \multicolumn{2}{|c|}{ Social Status } \\
\hline \multirow{2}{*}{} & & & & & $\begin{array}{c}\text { Cumulative } \\
\text { Percent }\end{array}$ \\
\hline \multirow{4}{*}{ Valid } & Frequency & Percent & Valid Percent & 28.0 \\
\cline { 2 - 6 } & Middle class & 56 & 28.0 & 28.0 & 52.5 \\
\cline { 2 - 6 } & Upper middle class & 49 & 24.5 & 24.5 & 100.0 \\
\cline { 2 - 6 } & Upper class & 95 & 47.5 & 47.5 & 100.0 \\
\cline { 2 - 6 } & Total & 200 & 100.0 & & \\
\hline
\end{tabular}

\section{Inferential Statistics}

Table 5 below illustrate the findings of the inferential statistics of this study:

Table 5

\begin{tabular}{|c|c|c|c|}
\hline Hypothesis & $\begin{array}{c}\text { Standardized } \\
\text { Path Coefficient }\end{array}$ & P-Value & Result \\
\hline $\begin{array}{c}\text { Ha-1: The consumer attitude mediates a } \\
\text { direct or no relationship b/w likeability } \\
\text { and consumer buying behaviour. }\end{array}$ & 0.65 & 0.005 & Accepted \\
\hline $\begin{array}{c}\text { Ha-2: } \text { The consumer attitude mediates a } \\
\text { direct or no relationship b/w credibility } \\
\text { and consumer buying behavior. }\end{array}$ & 0.54 & 0.002 & Accepted \\
\hline $\begin{array}{c}\text { Ha-3: The consumer attitude mediates a } \\
\text { direct or no relationship b/w personality } \\
\text { and consumer buying behaviour. }\end{array}$ & 0.21 & 0.030 & Accepted \\
\hline $\begin{array}{c}\text { Ha-4: } \text { The consumer attitude mediates a } \\
\text { direct or no relationship b/w } \\
\text { attractiveness and consumer buying } \\
\text { behavior. }\end{array}$ & 0.42 & 0.041 & Accepted \\
\hline
\end{tabular}

Following interpretations were made based on the inferential statistics:

1. The consumer attitude mediates a direct relationship b/w likeability and consumer buying behaviour. 
2. The consumer attitude mediates a direct relationship b/w credibility and consumer buying behavior.

3. The consumer attitude mediates a direct relationship b/w personality and consumer buying behaviour.

4. The consumer attitude mediates a direct relationship b/w attractiveness and consumer buying behavior.

\section{CONCLUSION}

The findings of the study demonstrate that celebrity endorsement intends to be an effective variable that creates a strong impact on consumers buying behaviour, their decisions, and attitudes towards products. The first attribute employed in this study namely "likeability" which comprises affection, pleasing and believability demonstrate that consumers are attracted towards the pleasing personalities of celebrities which create likeability for the celebrity and thus for the product endorsed by the celebrity. The second variable Credibility for the product is created through celebrity endorsement as credible personalities create a sense of trustworthiness which leads to buying intention. Similarly, the variable Personality and Attractiveness create celebrity persona which entices consumers to buy certain products endorsed by their favourite personalities, in order to purchase products used by celebrities and to impersonate them.

\section{LIMITATIONS OF THE STUDY}

This study is conducted based on certain assumptions and limitations. The study limitations thus confine the study from generalizations of the findings to a larger population. Similarly, due to certain assumptions, it is constructive to conduct similar studies on diverse groups of respondents with varied variables so as to understand the phenomenon under study, more rigorously. Following are thus a few assumptions and limitations of this study that restrict its scope:

- A different celebrity endorser of a different gender or different race may produce different results on consumer buying behaviour.

- Results would differ if respondents were exposed to a celebrity-endorsed advertisement for a longer period of time and more repeatedly.

- This study focused on limited variables of celebrity endorsement that are likability, credibility, personality, and attractiveness towards consumer attitude and buying behavior.

- These variables were able to explain to a certain extent the attitude and buying behavior of consumers.

- In this research, the population is limited to Karachi's' business students. 


\section{REFERENCES}

Abdurrahaman, D. T., \& Osman, Z. (2017). Development of a conceptual framework for Nigerian generation Y-ers' purchase intention and response towards indigenous celebrity-endorsed products: A PLS-SEM Study on Selected Mobile Service Providers in Nigeria. Journal of Administrative and Business Studies, 3(1), 49-59.

Abdurrahaman, D. T., Owusu, A., Soladoye, B. A., \& Kalimuthu, K. R. (2018). Celebrity-brand endorsement: A study on its impacts on generation y-ers in Nigeria.

Adam, M., \& Hussain, N. (2017). Impact of celebrity endorsement on consumers buying behavior. British Journal of Marketing Studies, 5(3), 79-121.

Ahmed, R., Seedani, S., Ahuja, M., \& Paryani, S. (2015). Impact of celebrity endorsement on consumer buying behavior. Available at SSRN 2666148.

Ahmed, R., Seedani, S., Ahuja, M., \& Paryani, S. (2015). Impact of celebrity endorsement on consumer buying behavior. Available at SSRN 2666148.

Choi, S. M., \& Rifon, N. J. (2012). It is a match: The impact of congruence between celebrity image and consumer ideal self on endorsement effectiveness. Psychology \& Marketing, 29(9), 639-650.

Jamil, R. A., \& Rameez ul Hassan, S. (2014). Influence of celebrity endorsement on consumer purchase intention for existing products: a comparative study. Syed Rameez ul Hassan, RAJ (2014). Influence of celebrity endorsement on consumer purchase intention for existing products: a comparative study. Journal of Management Info, 4(1), 1-23.

Muda, M., Musa, R., Mohamed, R. N., \& Borhan, H. (2014). Celebrity entrepreneur endorsement and advertising effectiveness. Procedia-Social and Behavioral Sciences, 130, 11-20.

Osei-Frimpong, K., Donkor, G., \& Owusu-Frimpong, N. (2019). The impact of celebrity endorsement on consumer purchase intention: An emerging market perspective. Journal of marketing theory and practice, 27(1), 103-121.

Priyankara, R., Weerasiri, S., Dissanayaka, R., \& Jinadasa, M. (2017). Celebrity endorsement and consumer buying intention in relation to the Television advertisement for perfumes. Management Studies, 5(2), 128-148.

Singh, R. P., \& Banerjee, N. (2018). Exploring the influence of celebrity credibility on brand attitude, advertisement attitude and purchase intention. Global Business Review, 19(6), 1622-1639.

White, D. W., Goddard, L., \& Wilbur, N. (2009). The effects of negative information transference in the celebrity endorsement relationship. International Journal of Retail \& Distribution Management. 